Philosophy and Progress: Vols. LIII-LIV, January-June, July-December, 2013 ISSN 1607-2278 (Print), DOI : http://dx.doi.org/10.3329/pp.v53i1-2.21947

\section{RIGHT TO INFORMATION: THE ROLES AND CONTRIBUTIONS OF INFORMATION PROFESSIONALS OF BANGLADESH}

\author{
Kazi Mostak Gausul Hoq*
}

\begin{abstract}
With increasing recognition of information as a critical ingredient of development, the issue of 'right to information' is gaining prominence quickly. Although Bangladesh parliament passed the Right to Information Act in 2009, larger cross-sections of people still suffer from an acute paucity of information because of lack of awareness and weak information infrastructure of the country. Globally, library and information professionals are making substantial contributions in the 'right to information' campaign, but in Bangladesh, their role in this regard is quite negligible. The paper highlights the roles and possible contributions of library and information professionals of Bangladesh in ensuring right to
\end{abstract}

\footnotetext{
* Associate Professor, Department of Information Science and Library Management, University of Dhaka. Email: kmgh.sharif@gmail.com
}

information for common people. It underscores the dilemmas faced by the information professionals in this regard and indicates ways for information professionals to play a more dominant role in the campaign for right to information.

\section{Introduction}

The role of information in the advancement of modern society is no longer a matter of contention. Its significance as a critical ingredient of development is now widely accepted. Development thinkers as well as information experts keep on exploring the dynamic use of information in various fields of development. In the later parts of the $20^{\text {th }}$ century, Fritz Machlup $^{1}$, Daniel Bell ${ }^{2}$ and Mark Porat ${ }^{3}$ pioneered the ideas of 'Information Economy' and 'Information Society' with information as the transforming resource for postindustrial society. Some other authors ${ }^{4}$ pioneered the view of information as a corporate resource, which like other resources such as people, money, raw materials, equipment and energy, should be managed to give a competitive edge. With phenomenal advancements in the fields of Information and Communication Technologies (ICTs) and the passing of Right to Information (RTI) Acts in various parts of the world also created huge interest among development thinkers, ICT and information professionals and information-enthusiasts in general about the problems and prospects of making information available to the larger cross-sections of people. Like other countries, this holds true for Bangladesh also. However, in Bangladesh, the role of information professionals in ensuring people's democratic and rightful access to information has not received due attention. As a result, the information professionals of Bangladesh are still in some dilemma as to what their role in the whole endeavour should be. 


\section{Right to information and the changing information infrastructure of Bangladesh}

The right to information is considered as a critical right because when people have up-to-date information on issues that directly and indirectly affect their lives, they tend to make better decisions, choose the right options and spend their time, efforts and resources judiciously. Right to information is closely linked with freedom of information, which has been defined by the United Nations' General Assembly ${ }^{5}$ as, 'the right to gather, transmit and publish news anywhere and everywhere without fetters. As such it is an essential factor in any serious effort to promote the peace and progress of the world.' However, 'Right to Information' has a slightly different connotation, which usually means the 'right ensured by legislation which guarantees access to information held by the Government ${ }^{6}$. Although the constitution of most countries guarantees freedom of information for the citizens, this is not always enough to ensure that the citizens receive all the information they need for their personal and collective wellbeing. This has necessitated the passing of formal laws which provides such rights to the people. Like many other democratic countries, Bangladesh passed the Right to Information Act in 2009. This law lays out the rules by which citizens can request the information, and an appeals procedure if they aren't satisfied with the government response. The law allows citizens to make requests for information from every government office, from the President and Prime Minister down to the Upazila. The law also compels disclosure by private organizations, such as companies, for the work they are doing with government funds. It also covers non-governmental organizations (NGOs) that receive funds from the government or foreign aid ${ }^{7}$.
Although laws and regulations are vital for safeguarding people's right, the laws alone cannot guarantee unhindered enjoyment of all democratic rights by people. Therefore, it requires a favourable atmosphere where people will find no obstacles in practicing their rights including right to information. It requires an information ecosystem, where the free flow of information is ensured and where people find effective platforms for meeting their information and knowledge needs. Well-stocked libraries and information centres act the bedrock of such an ecosystem. As Koga ${ }^{8}$ noted, 'In order to make the most of government information, "information intermediaries" must effectively connect citizens to government officials by managing and encouraging access to government information. Further, public libraries and archives can play the role of intermediaries for government information and contribute to the development of the knowledge infrastructure. Each public library or archive may manage different kinds of government information; however, they all share the role of providing public services relating to the information.' Libraries and information institutions have long been playing an instrumental role in making information available to people from all sections of the society. Byrne ${ }^{9}$ remarks, 'Libraries gather, organise and deliver the information the peoples of the world need for their health, wealth and pleasure. Libraries make available both the thoughts and dreams of great writers and the mundane documentation of day to day government. They present both the wisdom and the folly of the ages. They prize honest information - not propaganda and a diversity of voices, allowing users to select and evaluate.' Although the library and information infrastructure in Bangladesh is quite inadequate to meet the diversified and increasing information needs of its people, some positive initiatives have been undertaken in recent times, which have 
substantially increased the potential of the country's information infrastructure. The passing of the Right to Information Act is one such initiative. The others are as follows:

- More than 4500 technology based rural information centres have been set up in various parts of the country where rural people can receive technology-based information services.

- The Government has created a digital information repository of livelihood information which is called National e-Tathyakosh (National e-Content Repository). It has both online (www.infokosh. bangladesh.gov.bd) and offline (CD) versions. Besides, every district has its own web portal, which contains relevant information and links to government services.

- A number of innovative information-focused initiatives have been undertaken in the library and information domain. For example, The Centre for Information Studies, Bangladesh (CIS,B), an organization consisting mainly of teachers of library and information science and library professionals, has been organizing various programs at the grassroots level for strengthening information literacy.

- The use of ICT-based tools including social networks, is gaining prominence in information centres across Bangladesh. An increasing number of libraries have taken up digitization and knowledge repository building initiatives.

- Information and knowledge-focused activities are being promoted by many leading NGOs. One such initiative has been launched by D.Net, which has been providing livelihood information from both government and nongovernment sources to the marginalized people ${ }^{10}$.

\section{Problems and potentials for information professionals}

Karki $^{11}$ notes, 'For any nation to develop, it needs to have and provide relevant, updated and adequate information on food security, democracy, health, education, gender equality etc. Libraries can provide such access to information that would enable people lead gainful lives as they are skilled at acquiring, organizing, offering for use and publicly preserving materials irrespective of the form in which it is packaged in such a way that when it is needed it can be found and put to use.' With increasing recognition of information as a vital tool for development, the role of information professionals as facilitators for ensuring people's right to information is receiving greater attention than ever before. The ongoing movement of rural libraries and technology-based telecentre is an offshoot of such a realization. The role of information centres in creating an enabling environment where people, especially the disadvantaged and vulnerable groups, would be able to get their required information for improving their livelihood has been recognized by governments and NGOs worldwide, and the initiative from the government of Bangladesh for setting up Union Information and Service Centres bears testimony to this fact. Therefore, the responsibility of librarians and information professionals in making sure that people from every creed and class receive their required information is increasing day by day. They are no longer considered as mere preservers or gatekeepers of knowledge, but are required to act as dynamic informationintermediaries playing the roles of explorers, advisers, researchers, information experts and mentors at the same time. The role of information institutions has drastically changed and 
these are now seen as unique platforms from where to access worldwide information and knowledge residing in other libraries, information repositories, networks and knowledgebases. Today's information professionals are faced with an increasing number of tasks which call for in-depth subject knowledge and technical know-how. In order to perform these tasks, today's information professionals have to deal with a large number of issues, some of which have been pointed out by Vijaykumar and Vijaykumar ${ }^{12}$ :

- How to find information and how to use it?

- How do we evaluate the power of information in support of our organization's strategic aims?

- Effectiveness and cost-effectiveness (of services).

- Assessing the impact of services on the end user.

- Accessing the information that is needed.

- Information transmission.

The information professionals need to acquire requisite skills and qualifications for playing their role in this diversified information ecosystem. If they are to play any role, let alone a dominant role, in this emerging information society, they must find their own place in the whole set-up and they must do it immediately. Although the government of Bangladesh has been marching forward with its Digital Bangladesh initiative and seems to have placed the issue of information society high on its agenda, the role of information professionals in this initiative has not been clearly defined. For example, although the UISCs are supposed to be 'Information and Service Centres', their role as 'providers of information' is getting little or no attention ${ }^{13}$. The UISCs do not contain any information collection from which they can provide information and reference services to the users. Much emphasis is being laid on the ICT services of the UISCs, and hence, their role in information collection, processing, storage and dissemination is often overlooked. This is undermining the real potential of the UISCs who are not supposed to be limited only within their role as technology centres or cyber cafes. Similarly, since the role of information professionals in ensuring people right to information, especially public information, has not been clarified by the government, information professionals are always in a dilemma to understand what roles should they play in this regard. This clearly undermines their potential as information experts and intermediaries, who could expedite the process of information dissemination by providing value-added information services in this evolving knowledge society.

\section{Way out and way forward: possible roles for information professionals}

In spite of the enacting of the RTI act, people in Bangladesh still face great difficulties in accessing most of their required information from public authorities. Although the main reasons for this inability on the part of the common people are their lack of awareness as well as the apathy of government officials in discharging their public duty, the absence of a robust information ecosystem also is responsible for this dire situation. The problem is underlined by Iftekharuzzaman ${ }^{14}$, 'the information management system in Bangladesh is archaic, because of which the practical limitations in retrieving and providing information may also be conveniently exploited to deny and deceive information seekers. There is no alternative to developing a modern digital system of information management that would facilitate easy, dependable and secure archiving and retrieval with clear tracking indicators. Without this even with the best commitment and capacity the information system will remain insensitive to the letter and 
spirit of RTI.' The library and information professionals in Bangladesh have much to do to ameliorate the situation. Equipped with their specialized education, skills and experience, they could add a completely new dimension to the ongoing information-driven development interventions both at the government and the non-governmental levels. Their possible roles in this regard could be:

a. Information professionals could suggest ways and means for best implementing the ongoing informationdriven development activities carried out by GOs and NGOs. In the forefront of these activities are technology-based telecentres which are led by the Bangladesh Telecentre Movement (BTM). If information professionals could be engaged with this initiative, they would be able to design and manage information services extended by these centres.

b. Information professionals could act as advisers, facilitators and service providers in the government-led UISC endeavour. With their expertise and specialized education, they could transform the UISCs as true information centres where grassroots people would be able to receive their required livelihood information in an effective manner. The UISCs could be greatly benefited from the involvement of information professionals because, in that case, the informationprovision function of the UISCs will get much more emphasis.

c. One of the biggest roadblocks faced by the information professionals is the paucity of relevant information and locally developed contents. This has prompted the government of Bangladesh to encourage the development of local contents written in vernacular language. Since the information professionals have a good understanding of the information needs of common people, they could be engaged with this endeavour by planning and preparing contents best suited to the requirements of their users. The role of information professionals in 'reformatting and synthesizing raw information, combining expertise or consulting on a subject with access to relevant information sources and providing training or assistance to a user in accessing an information product ${ }^{\text {,15 }}$ would hugely benefit the users.

d. No development intervention could be sustained unless the people, to whom the intervention is addressed, are aware of its significance and importance. Information professionals could be engaged with the sensitization and awareness raising of community people, which will contribute greatly towards the sustainability of the development initiatives. The awareness raising campaign could be carried out through publications, television and radio programmes, posters, leaflets, stickers, banners, rallies, exhibition and folk media like jatra-pala, drama, songs, etc.of Creating awareness. This also includes 'hosting local forums where people can talk through problems, such as HIV/AIDS, community health, education, civil and human rights etc. $^{16}$.

e. Strengthening of the existing information infrastructure is a key for ensuring the common people's right to information. The information management and dissemination systems need to be invigorated by applying new techniques and technologies. Information-rich databases and knowledge-bases need to be developed and made available in every part of the 
country. Information professionals could not discharge their duties effectively unless a robust information system could be put in place.

f. In most of the developing countries, information literacy campaigns are strongly underway where information professionals are playing a dominant role. Information literacy has been defined as 'a set of abilities requiring individuals to recognize when information is needed and have the ability to locate, evaluate, and use effectively the needed information. ${ }^{17}$ Krolak $^{18}$ highlights the dynamism of the role of information professionals when he posits that they have evolved to become facilitators of information and lifelong learning opportunities with an emphasis on service, identifying user needs and communicating solutions. The information professionals of Bangladesh also could follow this example.

g. One of main obstacles to ensuring right to information is the huge information and knowledge gap that exists between urban and rural, educated and uneducated people. The role of library and information professionals in bridging this gap is extremely important. This can be done in many ways. Zimmer ${ }^{19}$, quoting Cullier, suggests, 'librarians should ... engage in reporting and synthesizing government activities, such as attending a city council meeting, summarizing it online and posting the minutes and supporting documents.' Koga ${ }^{20}$ observes, 'it is important for libraries to evaluate government information from the standpoint of the users of that information. For libraries, the evaluation of government websites can be observed as an extension of their evaluations of books.' h. Information professionals could speed-up and diversify their research and development initiatives in order to come up with new ways and means of sharing public information to the people. New techniques of disseminating public information through innovative means such as mobile phones and cultural programs could be envisaged and information professionals could suggest contents for these interventions which best reflect the specific needs of general people.

i. Information professionals could effectively lobby in various forums for putting the issue of right to information high on the agenda of GOs and NGOs. In this way, they can assist common people in receiving vital information at times of need. Vijaykumar and Vijaykumar ${ }^{21}$ observe, 'there is need for an effective lobby to communicate the value of libraries and the profession to politicians, the media and others who can influence public opinion.' In the developed world, information professionals participate in movements to promote or support information-focused initiatives by such activities like demonstrations, promotion through letter-writing, email, or word-of-mouth, fund-raising and social networking.

\section{Conclusion}

Proper implementation of the Right to Information act requires a strong and reliable infrastructure with proper focus on information technology support. Although it would take a considerable amount of time for developing this infrastructure, once established, it would contribute hugely in delivering information at the doorstep of people. The role and contribution of information professionals in this regard is a critical one. They can play a crucial role in bridging the digital 
divide and building the capacity of the larger cross-sections of people to access all the information they require. Information professionals are pledge-bound to provide the right information to the right user in the right personal way. If they are to discharge their professional responsibilities in an effective manner, they must strive to ensure the users' right to information by facilitating proper and unhindered use of information materials. In order to do this, they must act promptly, with strong conviction. Otherwise, their potential for taking part in nation building will be seriously undermined.

\section{References}

1. Machlup, F. (1980). Knowledge: Its Creation, Distribution, and Economic Significance. Vol 1, Knowledge and Knowledge Production (Princeton, NJ: Princeton University Press.

2. Bell, D. (1976). The Coming of Post-Industrial Society. New York: Basic Books.

3. Porat, M. (1997). The Information Economy, vol. 1. Washington, DC: Department of Commerce.

4. Marchand, D. A., \& Forest W. H. Jr. (1986). Infotrends: profiting from your information resources. New York: John Wiley

5. United Nations (1946). Calling of an International Conference on Freedom of Information, The proceedings of the United Nations' General Assembly. Retrieved on 12 July 2014 from http://daccess-dds-ny.un.org/doc/RESOLUTION/GEN/NR0/033/ 10/IMG/NR003310.pdf?OpenElement

6. Murad, M. H. \& Arshadul Hoque, M. (2010). The Right to Information Act in Bangladesh: An Analysis in the Light of Johannesburg Principles of Freedom of Information Legislation. IIUC Studies, Vol. 7, December 2010

7. ANSA-SAR [Affiliated Network for Social Accountability South Asia Region], (2009). Bangladesh Right To Information
Act 2009 at your fingertips. Retrieved on 10 July 2012 from ansa-sar.org

8. Koga, T. (2005). Government information and roles of libraries and archives: recent policy issues in Japan. Progress in Informatics, No. 1 (pp. 47-58)

9. Byrne, A. (2000). Promoting intellectual freedom globally through libraries: the role of IFLA. Libri, vol. 50 (pp. 57-65)

10. Raihan, A. [Ed.] (2007). Pallitathya: an information and knowledge system for the poor and marginalized: experience from grassroots in Bangladesh. Dhaka: D.Net (Development Research Network)

11. Karki, M. (2006). Right to Information and role of libraries and information system in Nepal. Retrieved on 11 May 2014 from http://www.nepjol.info/index.php/tulssaa/article/viewFile/254/ 255

12. Vijayakumar, J. K. \& Vijayakumar, M. (2000). Information freedom in a Democratic Society and the role of Librarians in cyber era. paper presented at a National Seminar on Information Policies and Cyber Laws, Bangalore (India), 4-6 December 2000. Retrieved on 9 August 2014 from http://eprints.rclis. org/7192/1/vijayakumarjk_02.pdf

13. Gausul Hoq, K. M. (2011). Information for Rural Development: assessment of needs and designing a dissemination system for Bangladesh. A thesis submitted in partial fulfillment of the requirements of the University of Dhaka for the Degree of Doctor of Philosophy. Dhaka: University of Dhaka

14. Iftekharuzzaman (2009). Implementing right to information in Bangladesh: opportunities and challenges. Key-note paper presented at the International Conference on 'RTI Implementation: Law, Institutions and Citizens' organized by the RTI Forum, Dhaka, 21-22 June 2009. Retrieved from http://rtiworkshop.pbworks. com/f/2009-06-BD-ImplementingRight-to-Informa- tion-in- Bangladesh-Iftekharuzzaman.pdf 
15. Iwhiwhu, E. B. (2008). Information Repackaging and Library Services: A Challenge to Information Professionals in Nigeria. Library Philosophy and Practice. Retrieved on 9 July 2014 from http://www.webpages.uidaho.edu/ mbolin/iwhiwhu3.htm

16. Onoyeyan, G. \& Adesina, O. I. (2014). A Literature Review of the Role of Libraries in the Provision of Information towards the Attainment of the United Nations Millennium Development Goals (MDGs) in Nigeria. Library Philosophy and Practice (ejournal). Paper 1069

17. American Library Association [ALA] (1989). Presidential Committee on Information Literacy. Final Report. Chicago: American Library Association

18. Krolak, L. 2005: The role of libraries in the creation of literate environments. Retriever on January 12, 2010 from http://www. ifla.org/files/literacy-andreading/publications/krolak.pdf

19. Zimmer, M. (2011). Libraries as freedom of information gazebos. Retrieved on 11 November 2011 from http://michael zimmer.org/2011/04/21/libraries-as-freedom-of-informationgazebos

20. Ibid., p. 55

21. Ibid., p. 4 